\title{
AN INVESTIGATION ON THE FOUNDRY CHARACTERISTICS OF UPPER RIVER BENUE SAND
}

\author{
E. O. ONCHE, A. RAJI AND L. ELUEME
}

(Received 24 January, 2007; Revision Accepted 9 May, 2007)

\section{ABSTRACT}

Foundry properties of upper River Benue sand were determined. Two categories if samples, A and B were prepared. Sample A contained $40 \mathrm{~g}$ of $\mathrm{H}_{2} \mathrm{O}, 40 \mathrm{~g}$ of bentonite in $1000 \mathrm{~g}$ of silica sand while sample B contained $50 \mathrm{~g} \mathrm{of} \mathrm{H}_{2} \mathrm{O}, 50 \mathrm{~g}$ of bentonite in $1000 \mathrm{~g}$ of silica sand. Seven specimens each were produced from both samples for various tests. The results show that the permeability for sample $A$ is 135 while that for sample $B$ is 128 . The compactability is $45 \%$ for sample $A$ and $50 \%$ for sample $B$. The mouldability indices are 3.5 for sample $A$ and 2.1 for sample $B$. The moisture contents are $3.1 \%$ and $4.7 \%$ in samples $A$ and $B$, respectively. The green and dry compressive strengths are $39.37 \mathrm{kN} / \mathrm{m}^{2}$ and $1241.06 \mathrm{kN} / \mathrm{m}^{2}$ for sampie $A$ and $42.13 \mathrm{kN} / \mathrm{m}^{2}$ and $1413.43 \mathrm{kN} / \mathrm{m}^{2}$ for sample $B$ respectivcly. Tho green and dry shear strengths are $9.03 \mathrm{kN} / \mathrm{m}^{2}$ and $268.9 \mathrm{kN} / \mathrm{m}^{2}$ for sample $A$ and $9.72 \mathrm{kN} / \mathrm{m}^{2}$ and $310.26 \mathrm{kN} / \mathrm{m}^{2}$ for sample B respectively. These results conform to the AFS standard for foundry hence upper River Benue sand is considered suitable for foundry work.

\section{KEYWORDS: Sand, Mouldability, Compactability, Refraotoriness, Grain}

\section{INTRODUCTION}

Foundries are work establishments where ferrous and non-ferrous metals are first of all caused to be molten by the application of heat in a furnace and then cooled in a mould to yieid a unit solid mass (Shrayer,1949). In foundry practice, the quality of cast metal is dependent on the quality of mould and the grade of sand which may be fine, medium or coarse grain grade (Gupta, 1992). Moulding sand consists principally of sand, clays, water and additives. These ingredients when properly mulled or mixed together in the right proportions increase the plasticity and green strength of the sand. Basically, two types of sand exist and these are natural or synthetic sands. In natural sand, the only binders are water of about $6-8 \%$ and clay of about $18-30 \%$. Synthetic sands are artificially prepared in foundry by mixing clay free sand, binder (water and bentonite) and other materials as required.

Irrespective of the sand, modern day foundry takes into consideration certain important factors and characteristics of the sand which has helped to produce products with better dimensional accuracy, surface finish and high strength of castings. Some of the basic characteristics of foundry sand includes permeability, refractoriness, grain size distribution, grain shape, green and dry shear strengths, green and dry compressive strengths, compactability of the sand, moisture content, chemical resistance, electrical conductivity, thermal shock resistance of sand, and mouldability of the sand (Burns. 1986)

Grain shape may be angular, sub-angular, round, or compound. When rammed, round grains have least contact with one another; have high permeability and low strength Angular grains have defined edges. They give more strength and have low permeability and can interlock more easily. The compound grains are the combination of round and angular grain (Gupta, 1992) Silica sand being moulding sand is granulated in size. The size of moulding sand range from 53 to $4000 \mu \mathrm{m}$ and the shape could be spherical, angular, subangular or compound (Niebel ot al, 1989).

According to Gupta (1992), sands generally are specified based on their average size and shape. Grain size and shape affect both the escape of gases evolving from the moiten metal and the surface texture of the sand. Fine sand grains are closer to each other and impart more strength to the mould hence they ara desirable for small and intricate casting in which all the details of the mould are brought out more sharply. Fine sands with A.F.S GNS of 80-120 are hence used for aluminium casting (Niebel of al, 1989). Medium size grain with GNS of $60-70$ is used for large casting $4.54-45.36 \mathrm{~kg}$ where accuracy is not of much importance. Coarse size grains having A.F.S, GNS of $35-40$ are more suitable for steel casting since they are able to withstand the elevated temperature of steel compared to fine grains which get burnt-out at elevated temperature (Niebel ot al, 1989).

Grain size greatly influences the surface finish of a casting. The proper grain size is determined by the size of the casting (small, medium or heavy casting), the quality of the surface required and the surface tension of the molten metal. The AFS standard for the strength of casting sand meant for various castings is available in literature. Burns (1986) gave the range of properties of foundry sand as follows: green shear strength, $345 \mathrm{~m} 10.3 \mathrm{kN} / \mathrm{m}^{2}$; 'dry shear strength, 206.84 $379.21 \mathrm{kN} / \mathrm{m}^{2}$; green compressive strength, $31.03-48.26 \mathrm{kN} / \mathrm{m}^{2}$ dry compressive strength, $1310.00-2688.96 \mathrm{kN} / \mathrm{m}^{2}$ for smal and medium castings and as much as over $3447.38 \mathrm{kN} / \mathrm{m}^{2}$ for heavy castings. The refractory range of silica sand is 1500 $1850^{\circ} \mathrm{C}$

In foundry/casting processes, sand is one of the cheapest raw materials employed with the silica sand more frequently employed than any other type of sand such as quartz, zirconium, losterite, etc because of its lower cost and availability (Gupla, 1992). According to Nwachukwu and Nwajagu (1998). a good sand casting cannot be made without a good mould and a good mould is dependent on the desired foundry properties of the sand mixtures. In addition, efficient sand control is a very important factor in the production of quality casting arid reduction of the production cost through minimising defects in casting (Nwachukwu and Nwajagu, 1998). Therefore foundry properties were determined experimentally to ascertain the suitability of upper River Benue sand for foundry work.

\section{MATERIALS AND METHODS}

\section{Materials, Equipment, Tools and Apparatus}

The major materials used for this study are silica sand, distilled water, bentonite, moulded sand sample and $\mathrm{NaOH}$.

The equipment and tools used for this study include permeability testor. sand rammer, electric furnace, weighing balance, ramming machine, cylindrical tube muffler furnace, steel needle, porcelain dish, magnifying glass, beaker, moulding machins equipped with net, dark board, microscope, horizontal holder arip, electric oven. Others are A.F.S standard sieve, time clock, collector pan, jar, stirrer, universal strengih testing machine, and holder

E. O. Onche, Department of Mechanical Engineering, Federal University of Technolugy, P.M.B 2076, Yoia, Nigeria

A. Raji, Department of Mechanical Engineering, Federal University of Technology, P M.B 2076, Yola, Nigeria.

L. Elueme, Department of Mechanical Engineering, Federal University of Technology, P.M B 2076. Yola, Nigeria 
Sand Sample Preparation

Sand sample weighing $10 \mathrm{~kg}$ was collected from the bank of River Benues in Yola at 5 different locations and then mixed togather to atum unifom distribution and homogeneity of the sand. The sand was then washed with distilled water and sun dried for about d deys. Therenther. $1000 \mathrm{~g}$ of the sand mixture was weighed out and rixed with 409 of bentonise and $40 \mathrm{~g}$ of water and the resulant product was designated as sample A. Another $1000 \mathrm{~g}$ of sand was lalso collected and mixed with $50 \mathrm{~g}$ of water and $50 \mathrm{~g}$ of bentonte; the mixture was designated ass sample B.

\section{Detormination of Pementabivisy}

Some quantity of Bumple A was placed in $5 \mathrm{~mm}$ diameter rammer tube of $12 \mathrm{~cm}$ height and was rammed throe times using a weight lever of $5 \mathrm{~kg}$. The resulting specimen in tube was then placed on a permeability testing machine (Electric Permmeter) and the machine was then switched on. The lever was adjuefor in "Thest" and enntrol volume of air pressure of $9.8 \times 10^{2} \mathrm{Nim}{ }^{2}$ wase applied for 15 seconds. The pointer became stable indicating the permeability number of the sand The experiment wes repeated for sample $\mathrm{B}$.

\section{Compactability Daterymantion}

Compactability was determined using the sand pammer attacher with a compactability scale. Sillica sand was poured into the cylndrical ramming tube whose height is known using specimen hopoer with a strike which was used to remove the excess sand. The specimen tubs was then placed in a ramming machine and five repeated impacts were delivered with the ais of hand lever weight. The compactability was then indicated by the compactability scale.

\section{Determinuthon of Rof}

Some quantity of sand sample was washed with distived water to remove impurities inherent in it. It was then sun dried for about 45 hours aner which 1000 of the sample was weighed out and placed in a porcelain dish in an electric furnace. The sample was intially heated to a tromparture of $1000^{\circ} \mathrm{C}$ then raised in steps of $100^{\circ} \mathrm{C}$ to $1300^{\circ} \mathrm{C}$ and finally raised in steps of $50^{\circ} \mathrm{C}$ until sintering ocurred. At cach temperature level, the sample was kept for at least 3 minutes and then traker out of the oven for cxamination with the aid of a magnifying giass for surface characteristics and to know if sinering has occurred by scratching with a steel needle.

\section{Detemination of moutchationdy}

The standard sample prepared was cylindrical in shape. The sample was wrighed and noted. If was then placed in a moulding machine having nets and the machine was then swiched on and allowed to rotate for deinite period of time (30s). The quantity of sand which passed through the ner was collected, weighed and noted.

The ratio of the loss in weight to the original weight expressed in \% was determined as follows.

$$
M_{0}=\frac{W-W_{1}}{W} \times 100
$$

The mouldabilisy index $\left(M_{i}\right)$ acconding to AFs standard A found thus:

$$
M_{1}=\frac{M_{1}}{2}
$$

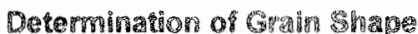

Silica sand $(100 \mathrm{~g})$ was measured out and washed with $1000 \mathrm{~cm}^{3}$ of distilled water in a beaker. It was then sun dried for about 3-4 hours after which it was examined on dakk board with the aid of a microscope with a magnification of 50 .

\section{Grean and Dr Compressive strength Detarathathon}

Two sanples were prepared. One was dried for $1 \mathrm{hr}$ in an electric oven at ${ }^{-1}$ temperature of $110^{\circ} \mathrm{C}$. Afterwards, if was removed and allowed to cool for thr. Each sample was placed on a horizontal plate in a uriversal testing machine and the arm of the tester (wheel) was adjusted to just touch the sample. The machine was then switched on and the arm was gradually and continuously adjusted towards the specimen. that is compressive force was applied until at point where failure of the material occurred. The value at which failure occurred was read from the calibration on the green compressive strength and noted.

\section{Groen and Dry Shear Strength Lazemination}

Two samples were prepared, green and dry. The shear strength of the green sample was datemined directly by placing it on the holder of the universal testing machine designed in way that shear stress was induced on the material specimen when the hand wheel was rotated until a point where failure resuted. The failure point was noted and recorded.

For dny shear, the specimen was placed in an oven and tried to temperature of $110^{\circ} \mathrm{C}$. Aftemareds, is was pemoved and allowed to cool in air for about thr. It was then placed on the flat platts on the tester and the hand wheel was rotated which induced a shear stress on the sample. The point of failure noted and recorded.

\section{Doteminaton of Grain Sice Distribution}

A medsured $100 \mathrm{~g}$ of silles sand was placed on the sieve-shaking machine. The machine was suithehed on and allowed to vibrate for about $15 \mathrm{~min}$; thereafter all the sand retained on sach sieve was then collected and weighed. The product was obtained by multiplying the preceding sieve ASTM No with retained weight on the current sieve. The AFS grain fineness number (CFN) was then deterrined thus:

$$
\text { GFN }=\frac{\text { Totul prodwct }}{\text { Tout swewe of percentage collected in each sieve }}
$$

\section{C12y Content Dotenmsmathon}

To conduct this test, some silica sand was dried in an clectric oven to $110^{\circ} \mathrm{C}$ to evaporate all the water present and $100 \mathrm{~g}$ of the cory sample was weighed out $\left(W_{1}\right)$. A measure of $20 \mathrm{~cm}^{3}$ of sodium hydroxide (MaOH) and $475 \mathrm{~cm}^{3}$ of distilled water was mixed with the sand in a jar. The conten was stirred for minutes and it was silled up to $6 \mathrm{~cm}$ with water the conient was then allowed to settle for 10 minutes. The water was then siphoned of to depth of exactly $5 \mathrm{~cm}$ in the boton of the jar.

This process was repeated one more firie. Distilled water was afded to $6 \mathrm{~cm}$ and suspension was allowed 10 settle for 5 minutes. The process was repeated and particles that failed to settle at the rate of $25 \mathrm{~cm}$ per minute were removed frem the sand grain. The remaining sand in the jar was removed, dried and weighed $\left(W_{2}\right)$. The ratio of the differences in weight to the original weight multiphied by 2 gives, according to AFS standard (Gupta. 1992), the clay conntant

$C_{c}=\frac{W_{1}-W_{2}}{W_{1}} \times 2$

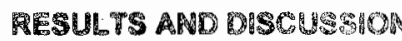

\section{Results} Tables 1-5
Results 8 o 
Table 1: Particle Size Analysis (Sieve Analysis) of Upper River Benue Sand

\begin{tabular}{|c|c|c|c|c|c|c|c|}
\hline $\mathbf{S / N}$ & $\begin{array}{l}\text { Aperture } \\
\text { (Mlcrons) }\end{array}$ & $\begin{array}{l}\text { ASTM } \\
\text { S/No }\end{array}$ & $\begin{array}{l}\text { Wolght } \\
\text { Retained, } \\
\mathbf{g}\end{array}$ & $\begin{array}{l}\text { \% Welght } \\
\text { Retained }\end{array}$ & $\begin{array}{l}\text { Cumulative } \\
\% \text { Weight } \\
\text { Retained }\end{array}$ & Product & $\begin{array}{l}\text { AFS } \\
\text { Graln } \\
\text { Fineness } \\
\text { Number }\end{array}$ \\
\hline $\begin{array}{l}1 \\
2 \\
3 \\
4 \\
5 \\
6 \\
7 \\
8 \\
9 \\
10 \\
11\end{array}$ & $\begin{array}{l}1400 \\
1000 \\
710 \\
500 \\
355 \\
250 \\
180 \\
125 \\
90 \\
63 \\
63 \text { Pan }\end{array}$ & $\begin{array}{l}14 \\
18 \\
25 \\
35 \\
45 \\
60 \\
80 \\
120 \\
170 \\
230 \\
-230 \\
\text { Pan }\end{array}$ & $\begin{array}{l}1.11 \\
2.59 \\
11.35 \\
25.80 \\
37.72 \\
14.91 \\
2.80 \\
0.89 \\
1.14 \\
1.60 \\
0.09\end{array}$ & $\begin{array}{l}1.11 \\
2.59 \\
11.35 \\
25.80 \\
37.72 \\
14.91 \\
2.80 \\
0.89 \\
1.14 \\
1.60 \\
0.09\end{array}$ & $\begin{array}{l}1.11 \\
3.70 \\
15.05 \\
40.85 \\
78.58 \\
93.48 \\
96.28 \\
97.17 \\
98.31 \\
99.91 \\
100.00\end{array}$ & $\begin{array}{l}0.00 \\
36.26 \\
204.30 \\
645.00 \\
1320.20 \\
670.95 \\
168.00 \\
71.20 \\
136.80 \\
272.00 \\
20.70\end{array}$ & 35.45 \\
\hline \multicolumn{5}{|l|}{ Total } & 100.00 & 3545.51 & \\
\hline
\end{tabular}

Table : Mouldability of Upper River Benue Sand Samples

\begin{tabular}{l|l|l|l|l|l}
\hline S/Mo & Sample & $\begin{array}{l}\text { Initial weight } \\
w(g)\end{array}$ & $\begin{array}{l}\text { Final } \\
\text { weight } \\
w_{1}(g)\end{array}$ & Mo & Mi \\
\hline 1 & $A$ & 1000 & 930 & 7.0 & 3.5 \\
2 & 3 & 1000 & 958 & 4.2 & 2.1 \\
\hline
\end{tabular}

Table 3: Permeability and Compactability of Upper River Benue Sand Samples

\begin{tabular}{l|l|l|l}
\hline S/No & Sample & $\begin{array}{l}\text { Penneability } \\
\text { number }\end{array}$ & Compactability \% \\
\hline 1 & A & 135 & 45 \\
2 & B & 128 & 50 \\
\hline
\end{tabular}

Table 4: Clay Content of Upper River Benue Sand

\begin{tabular}{l|l|l|l}
\hline S/No & $\begin{array}{l}\text { Initial weight } \\
w_{1}(g)\end{array}$ & Final weight $w_{2}(g)$ & $C_{c} \%$ \\
\hline 1. & 100 & 99.76 & 0.48 \\
\hline
\end{tabular}

The summary of results of all the various lests conducted on River Benue sand is given in Table 5 .

Table 5: Moulding Mixture Property of Upper River Benue Sand Samples

\begin{tabular}{l|l|l|l}
\hline S/No & Properties & Sample A & Sample B \\
\hline 1 & Compactability, \% & 45 & 50 \\
2 & Mouldability index & 3.5 & 2.1 \\
3 & Green shear strength (GSS), $\mathrm{kN}^{2} \mathrm{~m}^{2}$ & 9.03 & 9.72 \\
4 & Green compressive strength (GCS), $\mathrm{kN} / \mathrm{m}^{2}$ & 39.37 & 42.13 \\
5 & Dry shear strength (DSS), KN/m & 268.9 & 310.26 \\
6 & Dry compressive strength (DCS), $\mathrm{kN} / \mathrm{m}^{2}$ & 1241.06 & 1413.43 \\
7 & Permeability & 135 & 128 \\
8 & Moisture content, \% & 3.1 & 4.7 \\
\hline
\end{tabular}

\section{atgatom}

Cration Siro Distribution, Grain Fineness Number, Particle Sire amd Shase

The grain size distribution is as shown in Table 1. From the analysis, we can deduce that the River Benue sand is a coarse sand as it has GFN of 35.45 which satisfies the AFS Standard for coarse foundry sand with values of 35 40GFN (Niebel at al, 1989). It can, therefore, be used for heavy casstings and to cast steels since the particles size is large and is sub-angular in shape hence the particles can interlocks more easily thereby giving more rigidity and strength to the sand. Coarse grain size and too open texture encourage matal penetration and too fine a grade produces an ideal smooth skin which lacks the required permeability.

\section{The Molsture Content of the Sand}

As obtained from the experiment, the moisture content is 3.1 for sample $A$ and 4.7 for sample $B$ which is satisfactory when compared to the standard obtained from literature as 2-8\% moisture content (Faculty of Mechanical
Engineering, PSG College of Technology, 1989). Excessive moisture content tends to increase defects in castings. As the water content is converted to stearn at high temperature, its volume is increased tremendously; this excessive gas results to casting cefects like blow holes, porosity, etc. (Dibinin and Sokolov, 1985; Miknailov, 1989). Therefore, in order to obtain a satisfactory casting thare is need to control the moisture content of the sand.

\section{The Refractoriness of Sand}

This explains ability of the sand to withstand elevated ternperature without appreciable deformation during service condition. The selection of sand for foundry work strongly depends on the refractory and permeability property of the sand. The refractoriness of River Benue sand is between 1600 and $1650^{\circ} \mathrm{C}$ and according to Burns (1986), the AFS refractory standard for foundry sand falls in the range $\left(1400-1800^{\circ} \mathrm{C}\right)$.

\section{The Strength and Mouldability of the Sand}

The strength of sand describes the sands ability to withstand impact load without appreciable deformation. The 
green shear and compressive strengths compared to the diy shear and compressive strengths of the sand are usually less because of the lower bonding effect due to wetness. The dry strengths, on the other hand, have higher values because of the higher bonding effect due to dryness. The strengths of sand obtained for the two mould mixtures are GSS- 9.03 and $9.72 \mathrm{kN} / \mathrm{m}^{2}$; GCS- 39.37 and $42.13 \mathrm{kN} / \mathrm{m}^{2}$; DSS 268.9 and $310.26 \mathrm{kN} / \mathrm{m}^{2}$; DCS- 1241.06 and $1413.43 \mathrm{kN} / \mathrm{m}^{2}$. Comparing these values with those from Dieter cited in Guma (1998) and shown in Appendix 1, the sand is good considering the fact that it met the AFS standard for foundry sand. The mouldability values for the mould mixture is good' (4.2 and 7.0) when compared to the values from literature.

\section{CONCLUSIONS/ RECOMMENDATIONS}

Upper River Benue sand is good sand for foundry work. The sieve analysis test shows that the sand meets the sieve bulk distribution standard for foundry sand. The GFN of 35.45 shows that the sand is coarse hence can be used for casting steel and other heavy castings. It is sub-angular in shape hence it has more strength since it can interlock very easily thereby controlling permeability and porosity properties.

The Federal, State Governments and multi-national organisations are encouraged to harness this untapped resource. The gainful harnessing and effective utilisation of this deposit would go a long way in producing cast parts for our refineries, automobile industry and other areas of technology.

\section{REFERENCES}

Burns, T. A., 1986. The Foseco Foundry Man's Handbook ( $9^{\text {th }}$ ed.). Pergamon Press, London.
Dibinin, N. P. and Sokolov, E. A., 1985. Litaenoi Proizvodstwa. [Foundry Production]. In: A. M. Dalskii (Editors) Tekhnologia Konstruktsionnikh Materialov .[Technology of Structural Materials] Mashinostroeniye, Moscow, pp. 120-181.

Faculty of Mechanical Engineering PSG College of Technology, 1989. Design Data, MSDFV. Coimbatore, India.

Guma, T. N., 1998. Characteristic Foundry Properties of Kaduna River Sand, National Engineering Conference Series, 5(1):142 - 146

Gupta, R. B., 1992. Foundry Engineering. Prakanghan Publishers, New Delhi, Setga India.

Mikhailov, A. M.,1989. Metal Casting; Mir Publishers, Moscow

Nwachukwu, J. C and Nwajagu, C, O., 1998. Foundry Properties of Some Synthetic Moulding Sand Mixture, NI Prod. E Technical Transaction, 4(1):60-76

Niebel, B. W.: Draper, A. B. and Wysk, R. A., 1989. Modern Manufacturing Process Engineering. MC Graws-Hill Inc., Singapore.

Shrayer, M., 1949. Elementary Metallurgy (2 ${ }^{\text {nd }}$ ed.), Merrill publishers, New York, USA.

Appendix 1

Satisfactory Sard Properles Ranges for Yarious Types of Casting

\begin{tabular}{|l|l|l|l|}
\hline Metal & $\begin{array}{l}\text { Green } \\
\text { compression } \\
\text { strength, } \mathrm{kN} / \mathrm{m}^{2}\end{array}$ & Permeability, NO & $\begin{array}{l}\text { Dry strength, } \\
\mathrm{kN} / \mathrm{m}^{2}\end{array}$ \\
\hline Heavy steel & $70-85$ & $130-300$ & $1000-2000$ \\
Light steel & $70-85$ & $125-200$ & $400-1000$ \\
Heavy grey iron & $70-105$ & $70-120$ & $350-800$ \\
Aluminium & $50-70$ & $10-30$ & $200-550$ \\
Brass and bronze & $55-85$ & $15-40$ & $200-860$ \\
Light grey iron & $50-85$ & $20-50$ & $200-550$ \\
Malleable iron & $45-55$ & $20-60$ & $210-550$ \\
Medium grey iron & $70-105$ & $40-80$ & $350-800$ \\
\hline
\end{tabular}

Source: Dietert in Guma (1998) 